kálnych jednotiek, ktoré má štruktúrny charakter - nemá teda l'ubovol'ný, a preto na prvom mieste je vždy uvádzaný ich základný význam a na d’alších miestach odvodené, ale ustálené, lexikalizované významy (s. 29). Osobitné výklady nájdeme $\mathrm{v}$ prípadoch homoným, ktoré, vychádzajúc z ich primárnej charakteristiky, autori spracúvajú dvojako - v samostatných heslách alebo $\mathrm{v}$ rámci jedného hesla. Každá charakteristika či analýza je podporovaná viacerými príkladmi tak, že čitatel' sa v slovníkovej časti bude správne a pohotovo orientovat'. Podobne možno konštatovat' o normativnom a štýlovom hodnoteni lexikálnych prostriedkov, ktoré pomáhajú použivatel'ovi orientovat' sa v slovnej zásobe pri výbere vhodného slova a rovnako aj v prípade jeho normatívneho statusu. V súvislosti s terminológiou autori upozorňujú na to, že ,...slovník môže podat' iba obmedzený rozsah informácií o súčasnej vel'mi rozvinutej terminológii najrozličnejších odborov“ (s. 35), teda prirodzene nie je náhradou za jednotlivé terminologické slovníky. Na konci informačno-výkladového textového bloku slovníka je stručný a výstižný pohl'ad na frazeologizmy; základným kritériom na ich spracovanie bola frekvencia výskytu ich používania a tematicko-štylistická závažnost' súvisiaca s aktuálnost'ou na osi zastaranost' - súčasnost'. V slovníku teda nenájdeme okrajové, zastarané a rovnako aj nárečové jednotky, ktoré majú viac-menej okazionálnu platnost'. Praktickou pomôckou pri štúdiu a používaní slovníka je dobre zvolený polotučný typ písma a značky, ktoré v prehl'adnej a komplexnej podobe uzatvárajú úvodnú čast' KSSJ.

Piate vydanie Krátkeho slovníka slovenského jazyka je moderné lexikografické dielo, v ktorom dominuje odborný opis slovnej zásoby súčasnej spisovnej slovenčiny; sú v ňom najdôležitejšie a v komunikačnej praxi najviac využívané slová prezentované v kondenzovanej, v normatívnej hláskovej a pravopisnej podobe, pričom sa v ňom ,...výraznejšie ako doteraz diferencujú spisovné a z druhej strany nespisovné prípadne nesprávne slová a výrazy“. Na záver konštatujem: verím(e), že najnovší Krátky slovník slovenského jazyka - 5. vydanie - bude mat' (lebo to vychodí z princípu veci) systémové (sic) miesto na každom verejnoprávnom pracovisku počnúc administratívou vlády, parlamentu a končiac samosprávami všetkých stupňov, v každej škole, vo firmách a spoločnostiach, v kultúrnych a masmediálnych inštitúciách, teda všade tam, kde sa komunikuje slovenským spisovným jazykom. Osobitne zdôrazňujem, že toto dielo je nevyhnutne intenzívne využívat' najmä v jazykovom vzdelávaní na všetkých stupňoch a úrovniach o to viac, že práve vo všestrannej práci s výkladovým normatívnym slovníkom naše jazykové vzdelávanie zaostáva. Žiaci a študenti - predpokladám - nemajú slovník na školských laviciach, a tak nevedia ho čítat', ani využívat'. KSSJ má - synekdochicky - (aj) národnú reprezentačnú funkciu, rovnako tak, ako ju má slovenský spisovný jazyk.

DOI: https://doi.org/10.31577/SlavSlov.2021.1.17

František Ruščák

\section{Vzácna lexikografická príručka (nielen) pre študentov slavistiky}

СТАЛЯНОвА, Н. - КРеЙчОвА, Е.: РечНИК на лингвистичните термини за студенти слависти А-Н. (български език - чешки език - полски език). София: Парадигма, 2019, 142 стр.

\section{СТАЛЯНОва, Н. - КРЕЙЧОвА, Е.: РечнИК на лингвистичните термини за студенти слависти О-Я. (български език - чешки език - полски език). София: Парадигма, 2020, 118 стр.}

V čase, ked' slavistika bojuje o prežitie s novými vednými odbormi (bulharská slavistika nie je žiadnou výnimkou), lexikografický výskum ešte celkom neustrnul. Každý rok vychádzajú lexikografické príručky, ktoré vypínajú medzery najmä v oblasti dvojjazyčných slovníkov (bulharčina a iný slovanský jazyk). Dlhé roky študenti, vysokoškolskí pedagógovia a vedeckí pracovníci pocitovali výrazný nedostatok prekladových, terminologických, tematických a iných dvojjazyčných slovníkov.

Na Sofijskej univerzite sv. Klimenta Ochridského vznikla hodnotná príručka zameraná štúdium v oblasti filologickej vednej disciplíny. V r. 2019 vyšiel prvý zväzok slovníka lingvistických termínov pre študentov slavistiky „Речник на лингвистичните термини за студенти слависти (А-Н)“, a v r. 2020 aj druhý zväzok (О-Я). Slovník je výsledkom riešenia grantových projektov НИС č. 80-10-65/10.04.2019 a 80-10-124/16.04.2020 Sofijskej univerzity sv. Klimenta Ochridského.

Autorky dvojzväzkového slovníka doc. Mgr. Elena Krejčová, PhD., z Masarykovej univerzity v Brne a doc. Nadežda Mihajlova-Staljanova, PhD., zo Sofijskej univerzity sv. Klimenta Ochridského sú absolventkami odboru slovanskej filológie na Sofijskej univerzite. Ide o slavistky s bohatými vedeckými skúsenost'ami aj v oblasti dvojjazyčnej lexikografie. Stručný pohl'ad do ich lexikografickej činnosti ukáže nielen ich lexikografické skúsenosti, ale aj dlhoročné pedagogické zázemie, pre ktoré aj toto dielo vzniklo.

$\mathrm{K}$ trojjazyčnému úvodu v prvom zväzku recenzovaného slovníka (bulharčina, čeština a pol’ština) v druhej časti pribudol aj predhovor v angličtine. Autorky uvádzajú, že Slovník lingvistických termínov je určený pre študentov a pedagógov so zameraním na štúdium slovanskej a bulharskej filológie. Zdôrazňuje sa, že slovník je vôbec „prvým vydaním svojho druhu vo vedeckej slavistickej literatúre a lexikografickej praxi v slovanských krajinách“. 
Slovník je vhodnou a užitočnou pomôckou pre študentov, doktorandov i vedeckých pracovníkov v oblasti slovanskej jazykovednej komparatistiky. Slovník je možné využit' ako praktickú príručku v rámci slavisticky orientovanej jazykovednej disciplíny (napr. gramatika, všeobecná jazykoveda, porovnávacia historická i synchrónna slovanská jazykoveda). Dobre poslúži ako pomôcka pri systematizácii filologického vzdelávania v slavistických a bulharisticky zameraných odboroch.

Východiskovým jazykom slovníka je preto bulharčina a slovníkové heslá sú usporiadané v abecednom poradí vzhl'adom na bulharskú alfabetu. Napriek tomu, že je slovník trojjazyčný, nejde o slovník s paralelnými prekladmi jednotlivých výkladov k lingvistickým termínom. Výklady lingvistických termínov však prezentujú jazykovedné názory a výsledky vedeckého bádania príslušnej národnej lingvistickej vedeckej tradície (príklady pozri v tabul'ke č. 1.).

Takto nemusia užívatelia vyhl'adávat' dodatočné zdroje.

Pokial' ide o štruktúru, terminologické jednotky zahrnuté do slovníka sú jednoslovné termíny alebo termíny utvorené zo slovných spojení.

Pri vyhl'adávaní konkrétneho heslového slova (termínu) sa nájdu aj varianty v závislosti od frekvencie odbornej praxe v jednotlivých použitých jazykoch. Možno uviest' príklad: a) v dvoch jazykoch sa medzinárodný termín používa ako základný pojem bez synoným, kým v tret’om jazyku sa uvádza domáci termín; b) v dvoch jazykoch sa používa konkrétny termín ako kalk či polokalk, ale $\mathrm{v}$ tret'om jazyku sa vyskytuje medzinárodný termín; c) v jednom alebo vo viacerých jazykoch sa ako východiskový termín uvádza domáci označenie a medzinárodný termín sa používa ako synonymum (pozri v tabul'ke č. 2). d) v niektorých alebo vo všetkých jazykoch sa domáci termín uvádza synonymom (pozri v tabul'ke č. 3). e) $v$ jednotlivých jazykoch sa použiva iný počet synoným heslového slova (pozri v tabul'ke č. 4).

Z pohl'adu používatel'a môže byt' prínosné, že jednotlivé termíny utvárajú priestor pre vnímanie vzt’ahu všeobecného a konkrétneho práve pri výklade pojmu z konkrétnej jazykovednej oblasti či úrovne (pozri v tabul'ke č. 5).

V niektorých prípadoch sa synonymné termíny v bulharskej zložke slovníka uvádzajú v samostatných heslových statiach, pričom frekventovanejší termín (bez ohl'adu na to, či je viazaný na národnú jazykovedu a je zaradený v slovníku podl'a bulharskej alfabety, alebo ide o medzinárodný termín), vždy obsahuje výklad pojmu a synonymný termín sa uvádza s odkazom na frakeventovanejší termín bez výkladu pojmu (pozri v tabul'ke č. 6).

V bulharskej časti slovníka sa vyskytujú aj prípady terminologických homoným, ktoré nie sú určujúce pre českú či pol'skú čast', lebo príslušné pojmy nepomenúvajú daný jav (pozri v tabul'ke č. 7).
Slovník lingvistických termínov ako lexikografická pomôcka pomôže nielen študentom slavistiky, ale súčasne poslúži ako užitočná metodologicko-didaktická lexikografická príručka pre učitel'ov. Treba však poukázat' na zámer rozšírenia tejto pomôcky o d'alšie lingvistické terminologické okruhy a d'alšie slovanské jazyky (slovenčina, ukrajinčina, srbčina a chorvátčina). Takéto viacjazykové rozšírenie slovníka zaiste prehíbi štúdium slavistiky a umožní aj komparáciu lingvistickej terminológie v jednotlivých slovanských jazykov (niekedy aj v neočakávaných aspektoch).

DOI: https://doi.org/10.31577/SlavSlov.2021.1.18

Diana K. Ivanova 
Tabul'ka č. 1

\begin{tabular}{|c|c|c|}
\hline Български & Чешки & Полски \\
\hline $\begin{array}{l}\text { АРГО (таен говор) } \\
\text { Езикът на отделна социална група, } \\
\text { който е създаден изкуствено, за да } \\
\text { се постигне езиково обособяване и } \\
\text { тайност на езиковото общуване. }\end{array}$ & $\begin{array}{l}\text { ARGOT } \\
\text { Typ sociolektu, (někdy záměrně } \\
\text { polosrozumitelne) výrazivo, popř. } \\
\text { i způsob jeho uživání, typické pro } \\
\text { sociálně okrajovou skupinu, hantýrka. }\end{array}$ & $\begin{array}{l}\text { ARGOT (wym. argo) } \\
\text { Odmiana języka używana przez jakąś } \\
\text { grupę zawodową lub środowiskową. }\end{array}$ \\
\hline $\begin{array}{l}\text { ВЪЗВРАТЕН ГЛАГОЛ } \\
\text { Глагол, който съдържа във формата } \\
\text { си възвратно местоимение се или } \\
\text { сu. }\end{array}$ & $\begin{array}{l}\text { ZVRATNÉ SLOVESO (reflexivum) } \\
\text { V češtině a některých jiných jazycích } \\
\text { je typem slovesa, jehož tvar je } \\
\text { tvořen plnovýznamovým slovesem } \\
\text { doplněným o volný morfém se nebo } \\
\text { si, kterým se děj slovesa obrací zpět na } \\
\text { původce děje. }\end{array}$ & $\begin{array}{l}\text { CZASOWNIK ZWROTNY } \\
\text { Czasownik mający w połączeniu } \\
\text { z zaimkiem się charakter formy } \\
\text { srony zwotnej. }\end{array}$ \\
\hline $\begin{array}{l}\text { КОМПОЗИЦИЯ } \\
\text { Начин на образуване на нови думи } \\
\text { чрез свързване на две или повече } \\
\text { словообразувателни основни, напр. } \\
\text { водоснабдяване }\end{array}$ & $\begin{array}{l}\text { KOMPOZICE } \\
\text { Způsob tvoření slov skládáním; } \\
\text { výběr, řazení a uspořádání prvků } \\
\text { v jazykovém projevu, např. kompozice } \\
\text { uměleckého nebo rétorického textu. }\end{array}$ & $\begin{array}{l}\text { KOMPOZYCJA } \\
\text { Tworzenie nowych leksemów } \\
\text { poprzez łączenie w jedną leksykalną } \\
\text { całość dwu (kilku) już w języku } \\
\text { istniejących leksemów. }\end{array}$ \\
\hline
\end{tabular}

Tabul'ka č. 2

\begin{tabular}{|l|l|l|}
\hline \multicolumn{1}{|c|}{ Български } & \multicolumn{1}{c|}{ Чешки } & \multicolumn{1}{c|}{ Полски } \\
\hline Аблаут & Ablaut & Apofonia \\
\hline Вьтрешна флексия & Vnitřní flexe (introflexe) & Introfleksja \\
\hline $\begin{array}{l}\text { Лингвистична география } \\
\text { (ареална лингвистика) }\end{array}$ & $\begin{array}{l}\text { Jazykový zeměpis } \\
\text { (areálová lingvistika) }\end{array}$ & $\begin{array}{l}\text { Geografia językowa (geografia } \\
\text { lingwistyczna, geolingwistyka) }\end{array}$ \\
\hline Междуметие & Citoslovce (interjekce) & Wykrzykniki (interiekcje) \\
\hline Местоимение & Zájmeno (pronomen) & Zaimek \\
\hline Ойконим & $\begin{array}{l}\text { Vlastní jméno místní } \\
\text { (místní jméno, oikonymum) }\end{array}$ & Ojkonim (nazwa miejscowa) \\
\hline Подлог (субект) & Podmět (subjekt) & Podmiot (subiekt) \\
\hline
\end{tabular}

Tabul'ka č. 3

\begin{tabular}{|l|l|l|}
\hline \multicolumn{1}{|c|}{ Български } & \multicolumn{1}{|c|}{ Уешки } & \multicolumn{1}{c|}{ Полски } \\
\hline Анимизация & Animizace & Animizacja (ożywienie) \\
\hline Деклинация (склонение) & Deklinace (skloňovaní) & Deklinacja \\
\hline Лексика & $\begin{array}{l}\text { Lexikon } \\
\text { (slovník; slovní zásoba, lexikum) }\end{array}$ & Leksyka \\
\hline $\begin{array}{l}\text { Метатеза } \\
\text { (преместване на звуковете) }\end{array}$ & $\begin{array}{l}\text { Metateze } \\
\text { (přesmykování) }\end{array}$ & $\begin{array}{l}\text { Metateza } \\
\text { (przestawka) }\end{array}$ \\
\hline
\end{tabular}


Tabul'ka č. 4

\begin{tabular}{|l|l|l|}
\hline \multicolumn{1}{|c|}{ Български } & \multicolumn{1}{|c|}{ Чешки } & \multicolumn{1}{|c|}{ Полски } \\
\hline $\begin{array}{l}\text { Административен стил } \\
\text { (административно-делови стил, } \\
\text { официално-делови стил) }\end{array}$ & $\begin{array}{l}\text { Administrativní styl } \\
\text { (administrativně-právní styl, úřední } \\
\text { styl, byrokratický styl, jednací styl, } \\
\text { hospodářský styl, institucionální } \\
\text { komunikace) }\end{array}$ & Styl urzędożwy, kancelaryjny \\
\hline $\begin{array}{l}\text { Деминутив } \\
\text { сумалително-гальовно } \\
\text { съществително име) }\end{array}$ & Deminutivum & $\begin{array}{l}\text { Zdrobnienia } \\
\text { (deminutiva, rzeczowniki zdrobniałe) }\end{array}$ \\
\hline $\begin{array}{l}\text { Дериват } \\
\text { Диалект (народен говор, местен } \\
\text { говор, наречие) }\end{array}$ & Dialekt (nářečí) & $\begin{array}{l}\text { Derywat (także: formacja } \\
\text { słowotwórcza, wyraz pochodny, } \\
\text { motywowany lub fundowany) }\end{array}$ \\
\hline
\end{tabular}

Tabul'ka č. 5

\begin{tabular}{|l|l|l|}
\hline \multicolumn{1}{|c|}{ Български } & \multicolumn{1}{|c|}{ Чешки } & \multicolumn{1}{c|}{ Полски } \\
\hline Граматика & Gramatika (mluvnice) & Gramatyka \\
\hline Граматичен строеж & Mluvnická (gramatická) stavba & System gramatyczny \\
\hline Граматична категория & Gramatická kategórie & Kategoria grmatyczna \\
\hline Граматична форма & Gramatický tvar & Forma językowa \\
\hline Граматично значение на думата & Význam mluvnický & $\begin{array}{l}\text { Gramatyczne (strukturalne) } \\
\text { znaczenie }\end{array}$ \\
\hline
\end{tabular}

Tabul'ka č. 6

\begin{tabular}{|l|l|l|}
\hline \multicolumn{1}{|c|}{ Български } & Чешки & \multicolumn{1}{|c|}{ Полски } \\
\hline $\begin{array}{l}\text { Култура на речта (езикова култура) } \\
\text { виж Езикова култура }\end{array}$ & & \\
\hline $\begin{array}{l}\text { Моносемантична дума (еднозначна } \\
\text { дума) виж еднозначна дума }\end{array}$ & & \\
\hline Обект виж допълнение & & \\
\hline
\end{tabular}

Tabul'ka č. 7

\begin{tabular}{|l|l|l|}
\hline \multicolumn{1}{|c|}{ Български } & \multicolumn{1}{|c|}{ Чешки } & \multicolumn{1}{|c|}{ Полски } \\
\hline $\begin{array}{l}\text { Наречие } \\
\text { речта, Която пояснява глаголи, } \\
\text { прилагателни имена и други } \\
\text { наречия [... }\end{array}$ & Adverbium (príslovce) & Przysłówek \\
\hline $\begin{array}{l}\text { Наречие } \\
\text { говори, сьвкупност от местни } \\
\text { характерни черти }[\ldots]\end{array}$ & Dialekt (náŕečí) & Narzecze \\
\hline
\end{tabular}

